\title{
Study on Measures for Animation Cultural Development in All Media Platforms
}

\author{
Yajie Sang \\ Yantai Nanshan University \\ Yantai, China 265713
}

\begin{abstract}
As an important cultural form in the all media age, anime culture involves such multi-disciplinary contents as arts, technology, aesthetics, marketing, media, etc., which is the product of art and media thought with high degree of integration. On the one hand, based on the communication function, artistic function, entertainment function and economic function of animation culture, especially animation culture under market economy transformation, there shall have been a deeper understanding of significant connotation of animation culture, and then its development role shall be grasped, to achieve the benign development of animation culture in all media platform. On the other hand, as an important pillar of cultural construction that pursues all media industry, animation culture will play an important role in the great development of China's cultural prosperity, which will influence the audiences with different ages, regions and values by virtue of its unparalleled advantage, and thus create a unique animation cultural identity.
\end{abstract}

Keywords—animation culture; all media platforms; measures

\section{INTRODUCTION}

As we all know, the animation culture is a cultural phenomenon on the basis of animation image, taking the mass media culture of consumption as the research object, with the modern all media platform as support. While creating happiness, animation culture also conveys cultural values. It's one way for people to observe, think and reflect animation reality. In my opinion, thanks to the impact of functional factors of animation culture, it is generated and develops stronger. Therefore, the research of functional factors of animation culture will be conducive to the smoother and better development of animation culture under all media platform.

\section{IMPROVE COMMUNICATION FUNCTION OF ANIMATION CULTURE}

Animation culture is a mixture of visual and auditory culture with animation image as the core, which has a coexistence relation with communication media. The main routes of animation culture transmission are such traditional communication media as film, television, newspapers, magazines and other media. However, with the development and growth of such new media as Internet and mobile Internet, the communication form of animation culture is turning to the all media platform. With the joint role of

Fund Project: Philosophy and Social Sciences Planning Project with Fund in Yantai 2015, No.: ytsk2015-015. traditional media and new media, animation culture can play a role of visual extension, auditory extension, feeling extension. It can also strengthen communication effect with it as the cultural carrier. As a result, animation culture has an advantage unmatched by other cultures. And with the continuous development of electronic media technology, the development and growth of all media platform has broadened the communication routes and scope of animation culture, enriching the communication channels and forms of animation culture, and promoting the continuous innovation of animation culture.

Specifically, animation culture is a leader in entertainment culture and mass culture. Such traditional mass media as film, television, newspapers, magazines and others are showing the development trend towards Internet and mobile Internet which are more entertaining, and the animation culture information conveyed by them are easily be understood and accepted by teenagers and groups of children. Just for this reason, the new media communication of animation culture has become a powerful complement to traditional forms of communication. We all know that any kind of cultural product is bearing the cultural forms and artistic value of a country or nation and reflects the different ideology form of the audiences, and animation culture is no exception. As an artistic form and culture communication form with particularly strong vitality, animation culture bears an important responsibility to carry forward the national culture and mission as animation culture can easily across the language barriers among different countries, different regions, different ethnic groups. In the process of animation culture communication, such artistic cultural communication form will not only influence the aesthetic thinking concepts and artistic aesthetics pf audiences in different regions, but also will make animation culture and value system subtly spread and penetrate into different regions, and finally to make the cultural identity generated among the audiences.

Finally, as a culture type, animation culture has the typical social and popular features. And its natural connection with mass culture can be reflected from the communication audiences, routes and contents. Meanwhile, it also has the features of practical utilitarian and entertainment, providing the functions of entertainment and stress relieve as a general cultural goods, thus to further meet aesthetic needs of the audiences. With the arrival of development and prosperity era of animation culture as well as the rapid development of communication media 
technologies, the animation culture conveyed by such traditional media as film, television, newspapers, magazines and others as well as such new media as Internet and mobile Internet are occupying people's daily lives, learning and entertainment space. Thus, with the progress of modern technologies, especially continuous improvement and application of all media communication platform, taking the audio-visual desires and psychological needs of the audiences as a starting point, have greatly promoted animation culture to walk out of our country, providing entertainment in different countries and regions, different cultures and values and the people with different identities and ages.

\section{ShAPE THE ARTISTIC FUNCTION OF ANIMATION CUlTuRE}

In China, the animation culture is in the edge position of mainstream culture, even so, it has extended to every aspect of people's living, learning and working. The animation shows with communicating, entertaining and commercial features that have been despised by people in the past have been more and more extended to the fields of film, television, advertising and many other fields. And the enthusiasm for animation by audiences, especially young people, children and other groups, are increasingly rising. For example, the broadcasting of Weslie series, Boonie Bears series and one of the films broadcasted in the summer 2015 - - "Monkey King Hero is Back" is the good evidence of Chinese animation boom.

As a highly integrated artistic expression form, animation has blended multi-disciplinary art forms such as literature, film, art, music and others, which is a manifestation of artistic ideas and artistic thinking. The artistic spirit reflected by it will influence audience's artistic ideology, artistic value, artistic standards and other aspects, which is an important form for it to express artistic viewpoint and to convey artistic concept. And audiences achieve their understanding and preference for animation culture just through its artistic feature. From the artistic point of view, the stirring and happy visual images shaped by animation have satisfied the audiences' wonderful fantasy. Its exquisite visual experience and aesthetic characteristics of dynamic beauty, formal beauty and conception beauty, has made aesthetic of animation reached a higher level, and promote it to become unique animation aesthetics. Thus, to shape the artistic function of animation culture, we need to convey the artistic and aesthetic animation culture from the aspects of artistic ideology, artistic value, artistic standards and aesthetic characteristics, and to lay a solid foundation for the development of animation within all media platform.

\section{ENHANCE ENTERTAINMENT FUNCTION OF ANIMATION CULTURE}

The nature of animation culture is entertainment. With the development of market economy and society, the needs at material level are basically met. Audiences are paying more and more emphasis on such spiritual needs as creative culture, especially the animation culture. As we all know, living in the fast-paced modern society, audiences are often facing the repression which is difficult to relieve from different aspects and the psychological stress of working, learning and living. The surrealistic sense and fantastic qualities, the gorgeous and fresh beautiful image, exaggerated personality image, humorous dialogue language and distinctive entertainment story structure of animation culture will enable the audience to ease the living, working and learning pressure as well as the anxious and uneasy feelings resulted by intense competition in an intimacy and entertainment environment, and to realize the emotional expression that cannot be experienced in real social life, thus to ultimately meet the maximization of self spiritual needs. From the entertainment point of view, what the animation cultural spirit conveys is a kind of lifestyle, which is coordinate with audiences' self recognition structure and self entertainment value orientation.

In particular, through the rapid development in last decade, China's animation culture has received more and more audiences, becoming more and more popular, and the design thinking of all ages has been demonstrated in the creation level. However, as the entertainment emotion expression of audiences is restricted by family economic capacity and the capability of consumer spending, the main audiences of animation culture are still the teenagers and infant children who are in the growth stage. Based on this, through the attraction of teenagers and children by entertaining animation culture to form a strong spiritual and cultural level and the value system, thus to influence the personality formation and moral spirit development of teenagers and children in a subtle way. The courage, wisdom and justice behavior of the roles in animation culture can be recognized by parents as well as teenagers and children, which will influence their behavior and the formation of moral character without doubt in a subtle way, thus ultimately to serve the communication and development of animation culture in a larger scope and wider area.

\section{STRENGTHEN ECONOMIC FUNCTION OF ANIMATION CULTURE}

As mentioned above, the fast living, working and learning pace of modern society has made audiences' thinking mode and lifestyle changed dramatically. They need to soothe and release psychological stress by virtue of the entertainment factor of animation culture, and enjoy the fun it has brought about, meeting the needs of spiritual pleasure of animation culture. Whereby, audiences' needs or desires of spiritual pleasure will be achieved through the economic function of animation culture.

Animation culture brings the joyful experience of body and mind to audiences with diverse, flexible and colorful forms, and enables them to obtain joyfulness and satisfaction. Thus, the animation culture which is filling with entertainment features has a unique economic value and material rewards. And relying on the development path of animation culture on the basis of this, to expand the field of animation derivative products, and to gradually form the interactive circulating economic model of development and profitability in terms of animation film, television, books, 
magazines, audio and video products as well as such animation derivative products as apparel, toys and video games related to animation roles. Thus, as an important part of the entertainment economy era - the complete and efficient industrial chain formed by animation culture industry, continuously provides the products and services with entertainment value and economic value to the audiences, making it a new boost growth point for economic development. And ultimately, find the full profit point and end point for the animation culture through the economic function of animation culture.

\section{CONCLUSION}

As a cultural form, animation culture has conquered the audiences in different areas and different regions with its unique visual attraction and auditory appeal in all media platform. But as an important part of the cultural industry, animation culture has also successfully crossed the gap of language, age, gender, geography and race, reflecting its unparalleled advantage, and has a broad space for development. From the specific analysis on animation culture from the perspective of cultural research of animation culture's communication function, artistic function, entertainment function and economic function as well as the development adopting to animation culture, it can be seen that animation culture takes entertainment function as the core, takes economy function as a driving force, and takes artistic function and communication function as a support. Therefore, a careful analysis and grasp of different functions of animation culture, will promote structure optimization and upgrading of animation industry, enhance the international influence of China's animation culture. Especially in the all media platform, the study on different artistic functions of animation culture is of very important significance for China's animation development.

\section{REFERENCES}

[1] Wang Wulin. Study on Chinese Animation Culture Communication and Its Competitiveness under the Background of Globalization. China Publishing Journal. 2010, Vol. 8(08) 19-22.

[2] Zhao Xin, Chang Xin. Cross Culture Communication in Television Animation. Art Science and Technology. 2015, Vol. 7(07).

[3] Shao Ning. Study on Chinese Animation Crossover Phenomenon under the Background of Global Integration. Master's Thesis of Nanjing University of The Arts, 2013.

[4] Liu Cuicui. Study on Chinese Animation Culture Communication. Art Education, 2014(11)

[5] Pan Jian. How Does Chinese Animation "Walk Out"?---On Current Situation, Problems and Measures of Chinese Animation. Dongyue Tribune, 2012, 33(1). 